\title{
The Improvement of Science Learning Outcomes of Primary School Students Through the Model of POGIL-Supplemented With the Student Worksheet
}

\author{
Ummu Aiman ${ }^{1 *}$, Sunimbar ${ }^{2}$, Uslan $^{3}$ \\ 1,2,3 Department of Elementary Teacher Education, Universitas Muhammadiyah Kupang, Jl. K. H. Ahmad Dahlan, \\ Kayu Putih, Kupang city, East Nusa Tenggara \\ *Corresponding author. Email: aimanpgsdumk93@gmail.com
}

\begin{abstract}
This research aimed at discovering the improvement of students' learning outcomes using the mode of POGILsupplemented with the student worksheet. This research was a quasi-experiment using post-test only control group design. The data of learning outcomes ability were obtained through test. The data were then analyzed using descriptive statistical technique and ANOVA. The results of $t_{\text {value }}$ were 7,397 and the $t_{\text {table }}=4,00$ (with the significance level of 5\%). It meant that the $t_{\text {value }}>t_{\text {tabel}}$; thus, it could be concluded that there was a significant difference on the students' learning outcomes which was taught by the model of POGIL- supplemented with the student worksheet and the students who taught using the conventional method. From the average scores, the learning outcomes were in the very high category, in which the Mean was 76,17, while the control class was in the moderate category with the Mean results of 64,80 . Therefore, the conclusion is that the model of POGIL using the Student Worksheet $(L K S)$ supplement can improve the stduents' learning outcomes Of $4^{\text {th }}$ grade in State Primary School of Oeba 3, Kupang City, especially on the material of "save energy"..
\end{abstract}

Keywords: Model of POGIL-Supplemented with the Student Worksheet

\section{INTRODUCTION}

Human life is very dependent on various natural events; thus, an understanding science is needed. Structured science discusses natural events based on the results of experiments and observations made by humans. Science is very important especially for primary school students [1-4]. The primary school phase is the beginning of implantation of information or the beginning of the education process $[5,6]$, so that the students have adequate understanding [7-10], and the students can implement science in solving problems [7,9,11-13].

Science learning in school has goals so that the students learn and they are getting used to be able to apply various science concepts [14-16] in raising awareness of God Almighty [17-20], the students are involved in the advancement of science and technology [20-24], as well as being active in environmental Conservation [25-28]. Learning science in primary schools should provide direct learning experience based on the development of scientific process skills and attitudes [4,29-32]. Giving direct learning experiences to primary school students can be done by means of giving assignments to solve simple problems related to their daily lives, so that they can actively motivate the students to compile their knowledge, and finally be able to obtain the expected learning outcomes of science [33-37].

Contrary to these ideal expectations, the observation results in IV A class of State Primary School of Oeba 3 Kupang City, East Nusa Tenggara Province on the academic year of 2019/2020 illustrated a science learning outcome that is still low. Form 30 students in that class, there is only $40 \%$ students (12 students) who are complete, while $60 \%$ students (18 students) are stated to be not complete since their learning outcome scores does not meet the Minimum completeness Criteria (the school sets minimum limits of 65). This is due to the learning activities, the teachers still use conventional method, teacher-centered, and monotonous. Additionally, Other problems encountered rarely provide opportunities for the students to conduct observational activities, problem-solving, or simple experiments with the help of student worksheets. This impacts on the conceptual understanding owned by the students that only limited to memory, so that the students' learning outcomes are low. 
In line with the demands regarding renewal in the teaching and learning process, it is necessary to implement a learning model and learning media so that the learning material delivered is easily understood by the students. In this regard, one of the learning models that has potential and in line with several previous studies is the Process Oriented Guided Inquiry Learning (POGIL) model supplemented with the student worksheets.

POGIL is a learning model based on the principle constructivist-cooperative [38]- and problem-solving [39,40], oriented to the best strategies of students in learning, through "simple research" [41,42]. There are three structural elements in the model of POGIL i.e. "learning cycle based activities, use of self-managed class groups, and use of specific roles for group members" [43]. The researchers' consideration in choosing the model of POGIL in the quasi-experiment is because in this model the students' learning activities are directed in the process of gaining and understanding the concepts, more constructive and interactive, and each student has their respective roles and contributions to find out the concepts [44,45]. The POGIL model is directed to practice the thinking, metacognition, collaboration, and motivation skills of success in the learning [46] as well as critical thinking and analysis of each student [47]. This is what distinguishes the POGIL model from various other inquiry-based methods.

Meanwhile, the student worksheets are an appropriate alternative source of learning for the students since it can help the students to add and strengthen information about the concepts being studied [48]. The student worksheets in accordance with the demands of the 2013 curriculum which emphasizes the learning process with a scientific approach in the learning science would greatly assist the students in the learning activities [49] and strengthen their science literacy [50-53], science process skills [54], collaboration and communication skills [55], and the students' activeness [56]. As learning material, the student worksheets are important in assisting the students to achieve good learning outcomes and academic achievement $[57,58]$.

Although several studies have shown that the application of the POGIL model at the college level provides positive results $[40,44,59-63]$ and even in the level of senior high school [42,64-66], yet there has not been any research about the implementation of POGIL for primary school level. Likewise, a research related to student worksheets at the primary school level, based on the Scopus database search, there are only two, i.e. "problem solvingbased students' worksheet on space material" [67] and "worksheet base on process skills in Curriculum 2013 [68].

Based on the background description above, it can be revealed that the POGIL model using $L K S$ (Student Worksheets) supplements is thought to have an influence on science learning (IPA), especially on the learning outcomes. However, the magnitude of this effect is not yet known, so this research needs to be done. Therefore, the research objective is to find out the improvement in student learning outcomes by using the model of POGILsupplemented with the student worksheets.

A real contribution of this research is to give quality improvement on science learning at primary school level, in which it is focused on the students' learning outcomes. The implementation of POGILsupplemented with the student worksheet in science learning is still very rare, especially in Indonesia. It can be stated that this research becomes a pioneer, so that the inspiration and the results of this research can be used as the next starting point and reference for the further researchers, especially those who focus on education, learning and science research at the primary school level.

\section{MATERIAL AND METHOD}

\subsection{Type of Research}

This research was quasi-experiment. The research design used was the post-test only control design.

\subsection{Place and Time of Research}

This research was carried out at State Primary School of Oeba 3 Kupang City, East Nusa Tenggara Province. This research was conducted on the academic year of 2019/2020.

\subsection{Sample and Sampling Technique}

The research sampling was carried out using random sampling technique, in which there were 2 classes. The IVA class become the experimental class that consisted of 30 students, while the IV B class was the control class that consisted of 32 students. Both of classes were used in this research, in which those classes had similar characteristics i.e. in the age of 9 to 10 years old, and came from the Timor ethnic. 


\subsection{Variables and Model Implementation}

The independent variable of this research was the learning model of POGIL-supplemented with the student worksheet, while the independent variable was science learning outcomes. The implementation of POGIL model was adopted from the syntax that widely implemented by previous researchers/other [69-71], whereas the control class use a conventional learning.

\subsection{Data Analysis}

The data collection was carried out by means of test technique and using one instrument of research i.e. multiple-choice test (consisted of 30 items). The data that had been obtained were then analyzed descriptively, by looking for the mean, median, modus, and standard deviation. The data analysis technique used the Analysis of Varian (ANOVA).

\section{RESULT AND DISCUSSION}

The data analysis recapitulation of students' learning outcomes in the control class was displayed on the Table 1.

Table 1. The Recapitulation of Descriptive Statistical Analysis

\begin{tabular}{lcc}
\hline Statistic & $\begin{array}{c}\text { Experimental } \\
\text { Class }\end{array}$ & $\begin{array}{c}\text { Control } \\
\text { Class }\end{array}$ \\
\hline Mean & 76.17 & 64.80 \\
Median & 75.00 & 70.00 \\
Modus & 80.00 & 70.00 \\
Standard & 13.752 & 9.224 \\
Deviation & & \\
Variants & 189.109 & 85.081 \\
\hline
\end{tabular}

The Table 1 showed that the students who taught using the model of POGIL-supplemented with the student worksheet obtained an average score of 76.17 , the median score of 75.00 , as well as the group frequency (modus) was 80.00 . The scores of 13.752 were the adalah standard deviation and 189.109 were the Varians. This meant that the average calculation score of learning outcomes from the experimental class was in the very high category. Based on the data of Table 1, the data of learning outcomes of experimental class could be served into the polygon curve form, in which it was showed in the Figure 1.

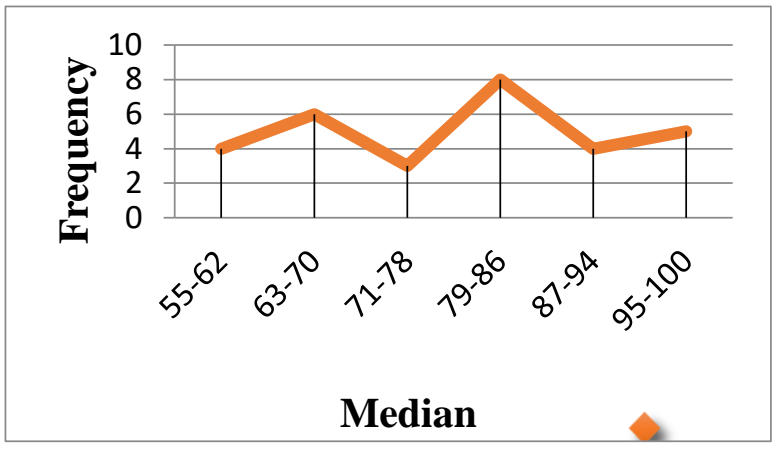

Figure1. Polygon Curve of Learning Outcome from the Experimental Class

The results of polygon curve indicated that the experimental class who taught using the model of POGIL-supplemented with the student worksheet showed negative curve. It meant that most scores tended to be high. The class which not taught using the model of POGIL-supplemented with the student worksheet (expository learning) got the average score of 64.80 , the median score was 70.00 , and the group frequency (modus) was 70.00. The score of 9.224 was the standard deviation and 85.081 were the Varians. Hence, the average calculation of students' learning outcomes for the class that taught using the model of POGIL-supplemented with the student worksheet $(L K S)$ was in the moderate category. The data of learning outcomes for the control class were served in the Figure 2.

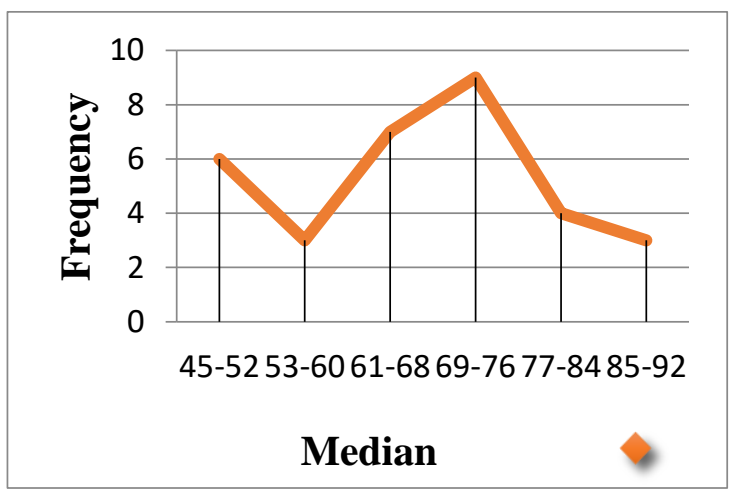

Figure 2. Figure1. Polygon Curve of Learning Outcome from the Control Class

Based on the Figure w, the polygon curve indicated that the class which not taught using the model of POGIL-supplemented with the student worksheet 
showed positive curve. It meant that most of scores tended to be in the low category.

The results of descriptive statistical analysis that carried out were then used as prerequisite test on the hypotheses. Normality data distribution test and homogeneity variance data distribution test. The data on the results of the normality distribution of students' learning outcomes in the experimental class showed the results of Chi-Square $\left(\mathrm{x}^{2}\right.$ value) and table $\left(\mathrm{x}^{2}\right.$ table), in which it was $0.058<11.070$ with the significance level of 5\%; hence, the results of learning outcomes for the experimental class was normally distributed. While in the control class, the results of Chi-Square ( $\mathrm{x}^{2}$ value $)$ was smaller than the value of Chi-Square table $\left(\mathrm{x}_{\text {table }}^{2}\right)$, in which it was $0.200<11.070$ with the significance level of $5 \%$. Consequently, the data of students' learning outcomes of control class were normally distributed. This could be concluded that the results data of post-test in both classed were proven to be normally distributed, so that it would be continued to the homogeneity test of data distribution.

The data distribution test of variance homogeneity of two variables showed that the value of $\mathrm{F}_{\text {table }}$ with the significance level of $5 \%$ was < $\mathrm{F}_{\text {value }}(0.067<3.481)$; thus, it can be stated that the data variance of both classes was the same. Then, it was continued to the hypotheses test. The analysis of t-test using the polled variance formula obtained the $t_{\text {value }}$ of 7.397 and the $t_{\text {table }}$ with the $d b=62$, in which the significant level of $5 \%$ was 4.00 . the calculation results indicated that the $\mathrm{t}_{\text {value }}>\mathrm{t}_{\text {table }}$ (7.397 > 4.00) so that the $\mathrm{H}_{0}$ was rejected and the $\mathrm{H}_{1}$ was received. It could be concluded that the class which got the learning model of POGILsupplemented with the student worksheet and the class which got the expository/conventional learning was significantly different.

Based on the results of data analysis, it was known that there were significant differences in the students' learning outcomes for the class which applied the model of POGIL-supplemented with the student worksheets compared to the students' learning outcomes using the expository/conventional learning. In addition, the average score of students' learning outcomes taught by the POGIL model-supplemented with the student worksheet tended to be higher than the control class. Significant differences in learning outcomes indicated the use of the model of POGILsupplemented with the student worksheets provided a great opportunity for students to play an active role and be directly involved in the learning process. This was because the learning activities in POGIL were designed in a learning cycle. The learning cycle in POGIL consisted of three stages, namely exploration, concept discovery, and application $[69,72]$.

In the exploration stage, the students were given the opportunity to look for the answers of the problems presented through a learning team and guided inquiry activities. The problems were presented in the form of questions. The questions would encourage the students to find out the answers to the questions given. At this stage, the students and groups discussed to explain and understand the student worksheets by developing, asking questions and testing the hypotheses. This stage did not present a clear concept, so that the students were motivated effectively to find out their own answers to each problem and draw the conclusions, as well as make hypotheses. Thus, at the exploration stage, the students played an active role and were directly involved in building up their knowledge so that the students' understanding of the concepts of science material was better. This was in line with the theory of constructivism which viewed that to develop scientific concepts, the students must play an active role to build up their own knowledge and explore the meaning of a material concept they were learning. [73].

At the concept discovery stage, the students presented the results of the discussion. Furthermore, the students along with their groups would make conclusions about the results obtained and interpret the ways adopted in solving the problems. The teacher guided the students to organize the data in order to find out the relationship between the concepts of learning material. Questions could be given by directing the students to identify the concepts and understanding them so that it could optimize the students' activities and learning outcomes [74].

In the application stage, the students practiced to solve the problems and released their knowledge. This stage provided opportunities for students to build up self-confidence in simple and relevant contexts in the daily life. The concepts obtained from the implementation of new contexts and realities in daily life would make the knowledge gained by the students more meaningful. The students' learning outcomes would be better when 
using their own concepts to solve the problems related to daily life $[75,76]$.

It was different from the learning carried out in the control class where the students tended to be passive in developing their knowledge. The learning process was still teacher-centered. In the learning, the teacher explained the learning material, questioned and answered to the students who were considered to have understood, and gave assignments to the students so that the teacher could give grade for the students. This made the students only listened and took notes about what was conveyed by the teacher without trying to find out the concepts learned.

The model of POGIL had been widely disseminated in various countries over the past two years [70]. The learning was packaged in a system that encouraged the students to work in teams and followed the paradigm of the learning cycle [45]. In the implementation of POGIL model, the class activities were students-centered and based on the environmental process of learning in team [77]. The model of POGIL encouraged an estimation that basic science concept would be understood and remembered longer when they were studied, discussed, and applied in practical real-world contexts [78]. The teacher acted as an active facilitator who observed the group activities, interacted to overcome problems, and lead the class discussions as needed. This supported why the students' learning outcomes tended to be better [79]. In fact, the results of other studies showed that at the end of the semester, many students thought that the learning process they experienced was easier than they previously thought [80]. This opinion illustrated the high motivation of the student learning. This was in line with the research that showed a significant difference in learning motivation between the students who taught using POGIL and conventional learning [65].

\section{CONCLUSION}

Departing from the research results, it can be concluded that there is a significant difference between the students' learning outcomes who taught by using the model of POGIL-supplemented with the student worksheet with the students who taught using the conventional learning. The average score results using the model of POGILsupplemented with the student worksheet is 76.17, in which it is on the high category. While the average score of the control class is 64.80 and it is on the moderate category. Thus, it is concluded that the learning model of POGIL-supplemented with the student worksheet influences on the students' learning outcomes of Natural Science (IPA) of the IV class at State Primary School of Oeba 3, Kupang City, in the academic year of 2019/2020.

\section{ACKNOWLEDGMENT}

The authors would to thank the Principle of State Primary School of Oeba 3 Kupang City, who had allowed this research to be carried out in the school. The authors also would like to express their gratitude to Ministry of Research, Technology and Higher Education-Indonesia who had funded this research through the Beginner Lecturer Research scheme of 2019.

\section{REFERENCES}

[1] Faisal and Martin S N 2019 Science education in Indonesia: Past, present, and future Asia-Pacific Sci. Educ. 5 1-29

[2] Braund M and Reiss M J 2019 The 'Great Divide': How the arts contribute to science and science education Can. J. Sci. Math. Technol. Educ. 19219 36

[3] Curran F C and Kitchin J 2019 Early elementary science instruction: Does more time on science or science topics/skills predict science achievement in the early grades? AERA Open 5 1-18

[4] Darling-Hammond L, Flook L, Cook-Harvey C, Barron B and Osher D 2020 Implications for educational practice of the science of learning and development Appl. Dev. Sci. 24 97-140

[5] Ferraz V and Neves A 2017 Childhood and schooling: Entrance of children in elementary school Educ. Real. Real. 42 345-69

[6] Jacob B A and Rockoff J E 2011 Organizing schools to improve student achievement: Start times, grade configurations, and teacher assignments (Brookings)

[7] Vieira R M and Tenreiro-Vieira C 2016 Fostering scientific literacy and critical thinking in elementary science education Int. J. Sci. Math. Educ. 14 659-80

[8] Rochman C, Nasudin D and Rokayah R 2019 Science literacy on science technology engineering and math (STEM) learning in elementary schools $J$. Phys. Conf. Ser. 1318 1-8

[9] Sujana A, Rachmatin D and Panjaitan R L 2019 Science and mathematics literacy of elementary school students related to water cycle J. Phys. Conf. Ser. 1318 6-12

[10] Prasasti P A T and Listiani I 2019 Guided experiments book based on SETS (Science, Environment, Technology, and Society) to empower science literacy for elementary school students $J$. Phys. Conf. Ser. 1318 1-7

[11] Kettler T 2014 Critical thinking skills among elementary school students: Comparing identified gifted and general education student performance 
Gift. Child Q. 58 127-36

[12] Ergul R, Simsekli Y, Calis S, Ozdilek Z, Gocmencelebi S and Sanli M 2011 The effects of inquiry-based science teaching on elementary school students' science process skills and science attitudes Bulg. J. Sci. Educ. Policy (BJSEP), Vol. 5 49-68

[13] Mogias A, Boubonari T, Realdon G, Previati M Mokos M, Koulouri P and Cheimonopoulou M T 2019 Evaluating ocean literacy of elementary school students: Preliminary results of a cross-cultural study in the Mediterranean Region Front. Mar. Sci. 6 1-14

[14] Osman K 2012 Primary science: Knowing about the world through science process skills Asian Soc. Sci. 8 $1-7$

[15] Fitzgerald A and Smith K 2016 Science that matters Exploring science learning and teaching in primary schools Aust. J. Teach. Educ. 41 64-78

[16] Tytler R 2007 Re-imagining Science Education Australian Education Review Re-imagining Science Education (Australian Council for Educational Research)

[17] Desstya A 2014 Kedudukan dan Aplikasi Pendidikan Sains di Sekolah Dasar Profesi Pendidik. Dasar 1 193-200

[18] Mardhiyyah L A, Rusilowati A and Linuwih S 2016 Pengembangan instrumen asesmen literasi sains tema energi J. Prim. Educ. 5 147-54

[19] Makmun M N Z 2014 Pengembangan Pembelajaran IPA (SAINS) dan IPS di MAdrasah Ibtidaiyah (Berbasis Integrasi Interkoneksi) Terampil J. Pendidik. dan Pembelajaran Dasar 1 79-98

[20] Iskandar R and Kusmayanti I 2018 Pendekatan science technology society: IPA di sekolah dasar $J$. Ilm. Pendidik. Guru Sekol. Dasar 2 200-15

[21] Kristyowati R and Purwanto A 2019 Pembelajaran literasi sains melalui pemanfaatan lingkungan Sch. J. Pendidik. dan Kebud. 9 183-91

[22] Pratiwi S N, Cari C and Aminah N S 2019 Pembelajaran IPA abad 21 dengan literasi sains siswa J. Mater. dan Pembelajaran Fis. 9 34-42

[23] Schellinger J, Mendenhall A, Alemanne N D, Southerland S A, Sampson V, Douglas I, Kazmer M M and Marty P F 2017 "Doing science" in elementary school: Using digital technology to foster the development of elementary students' understandings of scientific inquiry Eurasia J. Math Sci. Technol. Educ. 13 4635-49

[24] Akcay B and Akcay H 2015 Effectiveness of Science-Technology-Society (STS) instruction on student understanding of the nature of science and attitudes toward science Int. J. Educ. Math. Sci. Technol. 337

[25] Erdoğan M, Kostova Z and Marcinkowski T 2009 Components of environmental literacy in elementary science education curriculum in Bulgaria and Turkey Eurasia J. Math. Sci. Technol. Educ. 5 15-26

[26] Syarah E S, Yetti E, Fridani L, Yufiarti, Hapidin and Pupala B 2019 Electronic comics in elementary school science learning for marine conservation $J$. Pendidik. IPA Indones. 8 500-11

[27] Ardoin N M, Bowers A W and Gaillard E 2020

Environmental education outcomes for conservation: A systematic review Biol. Conserv. 241108224
[28] Situmorang R P and Tarigan S D 2018 Cultivating students' environmental awareness by creating bottle garden in school: A qualitative study J. Pendidik. Biol. Indones. 4 263-70

[29] Zulirfan Z, Rahmad M, Yennita Y, Kurnia N and Hadi M S 2018 Science Process Skills and Attitudes toward Science of Lower Secondary Students of Merbau Island: A Preliminary Study on the Development of MaritimeBased Contextual Science Learning Media J. Educ. Sci. 290

[30] Hernawati D, Amin M, Irawati M, Indriwati S and Aziz M 2018 Integration of project activity to enhance the scientific process skill and self-efficacy in Zoology of Vertebrate teaching and learning Eurasia J. Math. Sci. Technol. Educ. 14 2475-85

[31] Juhji J and Nuangchalerm P 2020 Interaction between scientific attitudes and science process skills toward technological pedagogical content knowledge J. Educ. Gift. Young Sci. 8 1-16

[32] Suryawati E and Osman K 2018 Contextual learning: Innovative approach towards the development of students' scientific attitude and natural science performance Eurasia J. Math. Sci. Technol. Educ. 14 61-76

[33] Gleason B L, Peeters M J, Resman-Targoff B H, Karr S, McBane S, Kelley K, Thomas T and Denetclaw T H 2011 An active-learning strategies primer for achieving ability-based educational outcomes Am. J. Pharm. Educ. 75186 (1-12)

[34] Weeks F H 2000 Behaviour problems in the classroom: A model for teachers to assist learners with unmet emotional needs. Diss. Abstr. Int. 6389

[35] Chin C and Osborne J 2008 Students' questions: A potential resource for teaching and learning science Stud. Sci. Educ. 44 1-39

[36] Abramovich S, Grinshpan A Z and Milligan D L 2019 Teaching mathematics through concept motivation and action learning Educ. Res. Int. 3745406 1-13

[37] Baranek L K 1996 The Effect of Rewards and Motivation on Student Achievement Master Thesis 285

[38] Kussmaul C L 2014 Guiding students to discover concepts and develop process skills with POGIL SIGITE 2014 - Proceedings of the 15th Annual Conference on Information Technology Education ed B. Rutherfoord, L. Li, S. V. de Ven, A. Settle and T. Steinbach (ACM) pp 159-60

[39] Mitchell E and Hiatt D 2010 Using POGIL techniques in an information literacy curriculum $J$. Acad. Librariansh. 36 539-42

[40] $\mathrm{Hu} \mathrm{H} \mathrm{H}$ and Kussmaul C L 2012 Promoting studentcentered learning with POGIL SIGCSE'12 Proceedings of the 43rd ACM Technical Symposium on Computer Science Education ed L. S. King, D. R. Musicant, T. Camp and P. Tymann (ACM) pp 57980

[41] Moog R S and Spencer J N 2008 POGIL: An overview ACS Symposium Series ed R. Moog, D. Bunce and J. Lewis (ACS) pp 1-13

[42] $\mathrm{Hu} \mathrm{H} \mathrm{H}$ and Shepherd T D 2014 Teaching CS 1 with POGIL activities and roles SIGCSE 2014 Proceedings of the 45th ACM Technical Symposium 
on Computer Science Education ed J. D. Dougherty, K. Nagel, A. Decker and K. Eiselt (ACM) pp 127-32

[43] Libby R D 2008 Phasing into POGIL ACS Symposium Series vol 994, ed R. Moog, D. Bunce and J. Lewis (ACS) pp 49-59

[44] Irwanto, Saputro A D, Rohaeti E and Prodjosantoso A K 2018 Promoting critical thinking and problem solving skills of preservice elementary teachers through process-oriented guided-inquiry learning (POGIL) Int. J. Instr. 11 777-94

[45] Moog R S, Creegan F, Hanson D, Spencer J and Straumanis A 2006 Process-Oriented Guided Inquiry Learning: POGIL and the POGIL Project Metrop. Univ. 17 41-52

[46] Aiman U and Sunimbar S 2020 Keterampilan proses sains siswa SD dalam pembelajaran inkuiri terbimbing berorientasi proses menggunakan suplemen LKS [Elementary students' science process skills in guided inquiry learning are process oriented using student worksheet supplements] J. Ilm.

Pendidik. Citra Bakti/Citra Bakti Educ. Sci. J. 7 7583

[47] Yuliani N P, Margunayasa G and Parmiti D P 2017 Pengaruh model pembelajaran POGIL berbantuan peta pikiran terhadap hasil belajar IPA siswa kelas V SD [The influence of POGIL learning models assisted with mind maps on the learning outcomes of science students in grade $\mathrm{V}$ elementary school] $\mathrm{J}$.

Educ. Technol. 1 117-23

[48] Yuanita Y and Yuniarita F 2018 Analysis of student's science practicum worksheet component of elementary school teachers in Gerunggang The 3rd Progressive and Fun Education International Seminar (Asosiasi LPTK Perguruan Tinggi Muhammadiyah (ALPTK-PTM)) pp 341-6

[49] Julianti D P and Sumarmin R 2018 The development of student worksheet based on scientific approach on environmental pollution topic for junior high school student grade VII Int. J. Progress. Sci. Technol. 10 11-8

[50] Sulistiyowati S, Abdurrahman A and Jalmo T 2018 The effect of STEM-based worksheet on students' science literacy Tadris J. Kegur. dan Ilmu Tarb. 389

[51] Ikhsan M K and Handayani 2016 The development of students' worksheet using scientific approach on curriculum materials Fourth International Seminar onEnglish Language and Teaching (ISELT-4) pp 74 87

[52] Marruf Nur F and Hidayah R 2018 Development of student worksheet based guided inquiry to practice scientific literacy in thermochemical chapter of XI grade in senior high school Proceedings of the Seminar Nasional Kimia - National Seminar on Chemistry (SNK 2018) Development vol 171 (Atlantis Press) pp 147-50

[53] Ekantini A and Wilujeng I 2018 The development of science student worksheet based on education for environmental sustainable development to enhance scientific literacy Univers. J. Educ. Res. 6 1339-47

[54] Payudi P, Ertikanto C, Fadiawati N and Suyatna A 2017 The development of student worksheet assisted by interactive multimedia of photoelectric effect to build science process skills Int. J. Sci. Appl. Sci.
Conf. Ser. 2273

[55] Sari K A, Prasetyo Z K and Wibowo W S 2017 Development of science student worksheet based on project based learning model to improve collaboration and communication skills of junior high school student J. Sci. Educ. Res. 1 1-6

[56] Fauziah A M and Nurita T 2019 Activities of students in using worksheet based on Contextual Teaching and Learning J. Phys. Conf. Ser. 1417 1-5

[57] Patresia I, Silitonga M and Ginting A 2020 Developing biology students' worksheet based on STEAM to empower science process skills $J P B I$ (Jurnal Pendidik. Biol. Indones. 6 147-56

[58] Asrizal, Amran A, Ananda A and Festiyed 2019 Effects of science student worksheet of motion in daily life theme in adaptive contextual teaching model on academic achievement of students J. Phys. Conf. Ser. 1185

[59] Vincent-Ruz P, Meyer T, Roe S G and Schunn C D 2020 Short-term and long-term effects of POGIL in a large-enrollment general chemistry course J. Chem. Educ. 97 1228-38

[60] Williamson N M, Metha G F, Willison J and Pyke S M 2013 Development of POGIL-style classroom activities for an introductory chemistry course Int. $J$. Innov. Sci. Math. Educ. 21 27-41

[61] Kussmaul C L, Hu H H and Pirmann T 2016 Special session: Helping students to develop communication, teamwork, and other process skills with POGIL SIGCSE 2016 - Proceedings of the 47th ACM Technical Symposium on Computing Science Education ed C. Alphonce, J. Tims, M. Caspersen and S. Edwards (ACM) pp 683-4

[62] Moore C, Black J, Glackin B, Ruppel M and Watson E 2015 Integrating information literacy, the POGIL method, and iPads into a foundational studies program J. Acad. Librariansh. 41 155-69

[63] Roller M C and Zori S 2017 The impact of instituting Process-Oriented Guided-Inquiry Learning (POGIL) in a fundamental nursing course Nurse Educ. Today 50 72-6

[64] Şen Ş, Yilmaz A and Geban Ö 2016 The effect of Process Oriented Guided Inquiry Learning (POGIL) on 11th Graders' conceptual understanding of electrochemistry Asia-Pacific Forum Sci. Learn. Teach. 17

[65] Yuliastini I B, Rahayu S, Fajaroh F and Mansour N 2018 Effectiveness of POGIL with SSI context on vocational high school students' chemistry learning motivation J. Pendidik. IPA Indones. Sci. Educ. J. 7 85-95

[66] Devitri N, Syafriani and Djamas D 2019 Validity of physics module nuanced model of process oriented guided inquiry learning (POGIL) to improve scientific literacy at 10th grade senior high school $J$. Phys. Conf. Ser. 1185 1-7

[67] Haking H, Syamsuddin A and Idawati 2020 Testing the validity of a problem solving-based students' worksheet on space material for 5th grade elementary school students J. Crit. Rev. 7 1246-50

[68] Subhan M, Oktolita N and Kn M 2018 Developing worksheet (LKS) base on process skills in Curriculum 2013 at elementary school grade IV,V,VI 
IOP Conference Series: Materials Science and Engineering vol 335 pp 1-8

[69] De Gale S and Boisselle L N 2015 The effect of POGIL on academic performance and academic confidence Sci. Educ. Int. 26 56-79

[70] Chase A, Pakhira D and Stains M 2013

Implementing process-oriented, guided-inquiry learning for the first time: Adaptations and shortterm impacts on students' attitude and performance J. Chem. Educ. 90 409-16

[71] Moog R S, Creegan F, Hanson D, Spencer J and Straumanis A 2006 Process-Oriented Guided Inquiry Learning: POGIL and the POGIL project Metrop. Univ. 17 41-52

[72] Lestari D P S, Sulastri M and Margunayasa I G 2016 Pengaruh model POGIL dan minat belajar terhadap hasil belajar IPA pada siswa kelas V SD e-Journal PGSD Univ. Pendidik. Ganesha Jur. PGSD 4 1-10

[73] Malik A, Oktaviani V, Handayani W and Chusni M M 2017 Penerapan Model Process Oriented Guided Inquiry Learning (POGIL) untuk meningkatkan keterampilan berpikir kritis peserta didik J. Penelit. Pengemb. Pendidik. Fis. 3 127-36

[74] Lamahala M H, Lamen S and Uslan U 2018 Pengembangan media jaringan epidermis tanaman jagung (Zea mays L.) yang tumbuh di Kota Kupang sebagai sumber belajar tambahan pembelajaran IPA SD berbasis kearifan lokal J. Ilm. Pendidik. Citra Bakti 5 15-25

[75] Ariandi Y 2017 Analisis kemampuan pemecahan masalah berdasarkan aktivitas belajar pada model pembelajaran PBL PRISMA, Prosiding Seminar Nasional Matematika pp 579-85

[76] Kurniawan M W and Wuryandani W 2017 Pengaruh model pembelajaran berbasis masalah terhadap motivasi belajar dan hasil belajar PPKn J. Civ. Media Kaji. Kewarganegaraan 14 10-22

[77] Kim S S H 2018 m-POGIL (modified-process oriented guided inquiry learning) based plastics laboratory ASEE Annual Conference and Exposition, Conference Proceedings ed A. Genau and J.

Callahan (ASEE) pp 1-13

[78] Eberlein T, Kampmeier J, Minderhout V, Moog R S, Platt T, Varma-Nelson P and White H B 2008 Pedagogies of engagement in science: A comparison of PBL, POGIL, and PLTL Biochem. Mol. Biol. Educ. 36 262-73

[79] Kussmaul C L, Mayfield C and Hu H H 2017 Process oriented guided inquiry learning in computer science: The CS-POGIL \& IntroCS-POGIL projects ASEE Annual Conference and Exposition, Conference Proceedings vol 2017-June, ed C. J. Kussmaul (ASEE) pp 1-7

[80] Schroeder J D and Greenbowe T J 2008 Implementing POGIL in the lecture and the Science Writing Heuristic in the laboratory - Student perceptions and performance in undergraduate organic chemistry Chem. Educ. Res. Pract. 9 149-56 